\title{
Impact of different diets' nutrition on the fitness and hemocytic responses of the greater wax moth larvae, Galleria mellonella (Linnaeus) (Lepidoptera: Pyralidae)
}

\author{
Hend O. Mohamed ${ }^{1 *}$ (D) and Abdulraouf Amro
}

\begin{abstract}
Background: The greater wax moth, Galleria mellonella (L.) (Lepidoptera: Pyralidae), is the major devastating insect pest of beekeeping industry all over the world; however their larvae were valuable to be the most favorable alternative invertebrate model. For this purpose, new-hatched larvae were reared on five different nutritional diets based on: old wax-comb (natural food); wheat flour diet (Triticum aestivum L.); soybean diet (Glycine max); wheat germ diet; and date syrup diet (Phoenix dactylifera L.) till reaching the fully grown $6^{\text {th }}$ instars to evaluate their fitness and hemocytic responses.
\end{abstract}

Results: Fully grown larvae from soybean diet had the highest rates of fresh $(280 \mathrm{mg})$ and dry weights (104 mg), water contents (175.6 mg), carbohydrates (1.97\%), total hemocyte count (THC) $\left(4746 / \mathrm{mm}^{3}\right)$, total soluble solid (TSS) (21.7\%), hemolymph protein concentration (HPC) $(1662.5 \mathrm{mg} / 100 \mathrm{ml}$ ), and hemolymph content (density $3.82 \mathrm{mg} / \mathrm{\mu l}$ and volume $70.35 \mu \mathrm{l} / \mathrm{larva}$ ), followed by wheat germ diet in comparable to the natural food. All suggested diets considered as rich protein-materials; recording high protein rates on their larvae (39.51-41.87\%), with only the exception of old wax-comb had the lowest one (36.63\%). Moreover, five types of hemocytes were classified in the larval hemolymph as (prohemocytes (PR), plasmatocytes (PL), granulocytes (GR), oenocytoids (OE) and spherulocytes (SP)), but with different rates related to different diets. Regardless the rearing diets, PR type was the most frequently recorded cell type (73.31\%) in hemolymph, followed by PL (8.37\%), and the lowest one was OE cells (5.82\%).

Conclusions: The suggested diets of soybean and wheat germ recorded the best results than the other diets used almost, and could be recommended as standard diets to mass-produce healthy and high-quality G. mellonella for in vivo experimentation and/or microbiological studies.

Keywords: Galleria mellonella, Experimental model, Biochemical parameters, Immunocompetent, Hemolymph, Total soluble solids

\section{Background}

The greater wax moth or honeycomb moth, Galleria mellonella (L.) (Lepidoptera: Pyralidae), is the major devastating insect pest of beekeeping industry all over

\footnotetext{
*Correspondence: honos_1@yahoo.com

1 Biological Control Research Department, Plant Protection Research

Institute, Agricultural Research Center, Giza, Egypt

Full list of author information is available at the end of the article
}

the world; causing severe damages in the storage honeybee wax combs, beehive farms, and the death of weakened or queenless colonies (Chandel et al., 2003; Singh et al., 2014). The economic importance of this pest was related to the larval feeding habits which tunneling into the combs with white silken webs and faeces' contamination, and thus led to the comb destruction (Kwadha et al., 2017; Sohail et al., 2017). Contrary, G. mellonella larvae were valuable to be an alternative invertebrate 
model over than traditional mammalian models due to their lack of legislative/ethical limitations, low maintenance costs, simplicity of mass production, short life cycle, larval size, rapid growth, high fertility, numerous offspring and ability to survive up to $37{ }^{\circ} \mathrm{C}$ (Altuntaş et al., 2021; Mukherjee et al., 2010; Ramarao et al., 2012; Stączek et al., 2020; Tsai et al., 2016). For these reasons, a wide range of microorganisms have been assessed on this insect model, for instance, fungal pathogens as Aspergillus fumigatus (Slater et al., 2011), Candida albicans (Brennan et al., 2002) and Cryptococcus neoformans (Mylonakis et al., 2005); bacterial species (Gram-positive and Gram-negative bacteria) (Loh et al., 2013; Miyata et al., 2003; Mukherjee et al., 2010; Olsen et al., 2011); and entomopathogenic nematodes (Metwally et al., 2012; Singh et al., 2014; Van Zyl \& Malan, 2015). Besides, these larvae used as a factitious host for mass rearing many insect natural enemies such as Microplitis spp., Archytas spp., Apanteles spp., Bracon hebetor, B. brevicornis, Pimpla turionellae, Antrocephalus galleriae, Solenopsis geminate, Camponotus compressus, Euborellia stall and Theridion spp. (Ashfaq et al., 2005; Hanumanthaswamy \& Rajagopal, 2017; Hasan et al., 2019; Kandil et al., 2020). Nowadays, it also recorded for insect physiology, immunity, biochemistry insecticide screening, and toxicology (Wu et al., 2016; Wojda, 2017; Gwokyalya \& Altuntas, 2019; Kaya et al., 2020; Altuntaş et al., 2021). In this response, nutrition is a vital parameter for mass rearing this insect model and subsequently their efficiency for microbiological studies (Krams et al., 2015). Naturally, larvae obtained a large amount of energy from honeycombs containing a large proportion of beeswax, some honey, caste off immature bee stages, and pollen residues (Jindra \& Sehnal, 1989; Kwadha et al., 2017), but with little protein rates (Mohamed et al., 2014). However, insects required important nutrients as (proteins, lipids and carbohydrates) to continue their vital activities. These nutrients maybe directly influenced by dietary ecology, food quality, and external chemical and physiological effects (Büyükgüzel, 2006). In this context, larvae were reared successfully on artificial diets with different ingredients under laboratory conditions to produce healthy and vigorous ones for biological purposes (Mohamed et al., 2014). Meanwhile, hemolymph is an accurate method to evaluate the quality of these diets (Bounias \& Morgan, 1990). Several studies have been focused on the hemocytes of G. mellonella larvae under different conditions (Kurt \& KAYIŞ, 2015; Wu et al., 2016; Boguś et al., 2018; Salem et al., 2020). Based on best knowledge, there is no detailed information on the influence of larval nutrition's on their quality as well as hemocytes of G. mellonella. Larval feeding on poor artificial diets could be caused developmental problems and sometimes led to their death (Kulkarni et al., 2012). Consequently, this study was designed to assess the impact of five nutritional diets (old wax-comb; wheat flour; soybean; wheat germ; and date syrup) on: 1) the larval fitness (Fresh and dry weight, water content, total percentages of protein, crude fat and carbohydrate), and 2) the hemocytic responses (THC, TSS \%, HPC, hemolymph content, and differential hemocyte counts \% (DHC)) of the greater wax moth, $G$. mellonella. Here, we hypothesized a diet that improves the mass-rearing, fitness and immunity of this larva to obtain an ideal experimental model for future biological research.

\section{Methods}

\section{G. mellonella culture}

Initial culture of G. mellonella used in this study was obtained from infested old wax comb collecting from a private apiary then transferred in suitable black bags to the insect rearing laboratory, Plant Protection Research Institute, Agricultural Research Center (ARC), Assiut Governorate, Egypt. Infested combs were divided into suitable pieces in clean plastic boxes $(20 \times 13 \times 8 \mathrm{~cm})$, covering with a piece of cloth and maintained under rearing conditions $\left(28 \pm 1{ }^{\circ} \mathrm{C} ;>60 \% \mathrm{RH}\right.$ and full darkness) until pupation. Pupae were collected and placed on clean plastic containers (2L capacity) until adult emergence and deposited the eggs. The neonate larvae were maintained on wax-comb for six successive generations during 2020, before being used in the experiments.

\section{The diets' preparation for G. mellonella rearing}

Newly emerged moths were kept in a plastic container (1L capacity) for egg-laying. A layer of $\left(\mathrm{A}_{4}\right)$ white copy paper was placed on the top of the container for collecting the deposited eggs, followed by a plastic cover with several holes. The insect rearing technique was conducted according to the methodology described by (Jorjão et al., 2018). Paper with cluster eggs were removed every $48 \mathrm{~h}$. and transferred to the new plastic container (25 cm diameter $\times 15 \mathrm{~cm}$ height) with equal quantity of each of the examined diets. One kilogram and 1000 cluster eggs for each diet were used at all experiments. The main five diets were based on: old wax-comb (natural food) used as a control (Mohamed et al., 2014); wheat flour diet (Triticum aestivum L.) (standard traditional diet) used previously as recommended diet (Kulkami et al., 2012); soybean diet (Glycine max); wheat germ diet; and date syrup diet (Phoenix dactylifera L.). These diets were prepared by mixing well all different amounts of row materials as described in (Table 1). All materials' components were commonly available in the local market. The newly hatched larvae (neonates) moved and fed on these suggested diets till reaching the fully developed 
Table 1 Dietary components (gm.) evaluated for rearing the greater wax moth larvae, Galleria mellonella (L.)

\begin{tabular}{|c|c|c|c|c|c|}
\hline \multirow[t]{2}{*}{ Materials } & \multicolumn{5}{|c|}{ Diet composition (g/kg) } \\
\hline & Diet (1) & Diet (2) & Diet (3) & Diet (4) & Diet (5) \\
\hline Bee wax-comb (Natural-food) & 1000 & & & & \\
\hline Wheat flour (Triticum aestivum L.) & & 300 & & & \\
\hline Soybean (Glycine max) & & & 300 & & \\
\hline Wheat germ (Triticum aestivum L.) & & & & 300 & \\
\hline Date syrup (Dibis) (Phoenix dactylifera L.) & & & & & 400 \\
\hline Dried skim milk & & 120 & 85 & 85 & 85 \\
\hline Brewer's yeast (Candida tropicalis) & & 30 & 85 & 85 & 85 \\
\hline Wheat bran & & 200 & & & \\
\hline Sugar powder & & & 310 & 310 & 310 \\
\hline Multivitamins \& minerals (Supravit $\left.{ }^{\mathrm{TM}}\right)^{*}$ & & & 2 & 2 & 2 \\
\hline Honey (ml) & & 150 & 218 & 218 & 118 \\
\hline Sugarcane molasses & & 200 & & & \\
\hline Total & 1000 & 1000 & 1000 & 1000 & 1000 \\
\hline
\end{tabular}

*Produced by GlaxoSmithKline S.A.E

$6^{\text {th }}$ instars to start the experiments (Fig. 1). The others larvae were used to maintain the insect colony and kept in other plastic jars for pupation and adult formation. Experiments were carried out in a completely randomized design with 4 replicates for each diet.

\section{Experimental design}

Effect of different diets on the fitness of G. mellonella larvae To evaluate the effects of different nutritional diets on the larval fitness, water content $(\mathrm{mg})$, total protein \%, crude fat $\%$ and carbohydrate \% were analyzed in the Central Laboratory for Chemical Analysis, Faculty of Agriculture, Assuit University, Egypt.

\section{Water content (mg)}

Fresh samples of fully grown larvae $(n=10)$ from each tested diet were previously weighed (fresh weight) and then transferred into an oven at $65{ }^{\circ} \mathrm{C}$ until reaching the constant weight. Samples were removed from the oven, cooled at room temperature and reweighed after dried. The water content (mg) was calculated by subtracting the dry weight from fresh weight.

\section{Total protein \%}

Dry samples of 20 larvae from each diet were ground to a fine powder; $100 \mathrm{mg}$ of these powdered materials were used for total nitrogen determination using Micro-Kjeldahl method according to (Kirk, 1950). The protein \% was measured by multiplying the nitrogen values with a constant 5.6 (Rabie et al., 1983).

\section{Crude fat $\%$}

Fat content was extracted from the tested diets using Soxhlet (EV-16) with petroleum ether according to the Association of Official Analytical Chemists methods (AOAC, 2000).

\section{Carbohydrate \%}

The anthrone sulfuric acid method was used to estimate the carbohydrate content according to (Hedge et al., 1962). The absorbance of the developed blue green color was measured at $630 \mathrm{~nm}$ against a blank containing only water and anthrone reagent by using spectrophotometer (UV2000 UV-Vis, China).

\section{Effect of different diets on the hemocytic parameters}

Larval hemolymph samples from each diet were collected by cutting the proleg on the abdominal segment with a fine pair of scissors to insure the best blood flow. The hemolymph droplets were used to study the following parameters:

\section{THC}

The extracted hemolymph was collected in Thoma white blood cell dilution pipette and was diluted (1:20) with a gentian violet solution. A few crystals of phenylthiourea were added to prevent the hemolymph melanization. Ten smears of hemolymph from each larval diet were examined to calculate the THC in the diluted hemolymph $/ \mathrm{mm}^{3}$ using Neubauer hemocytometer (DHC-No1) according to the formula of (Predetshensky et al., 1950):

$$
\mathrm{THC}=\frac{a \times 4000 \times b}{c}
$$



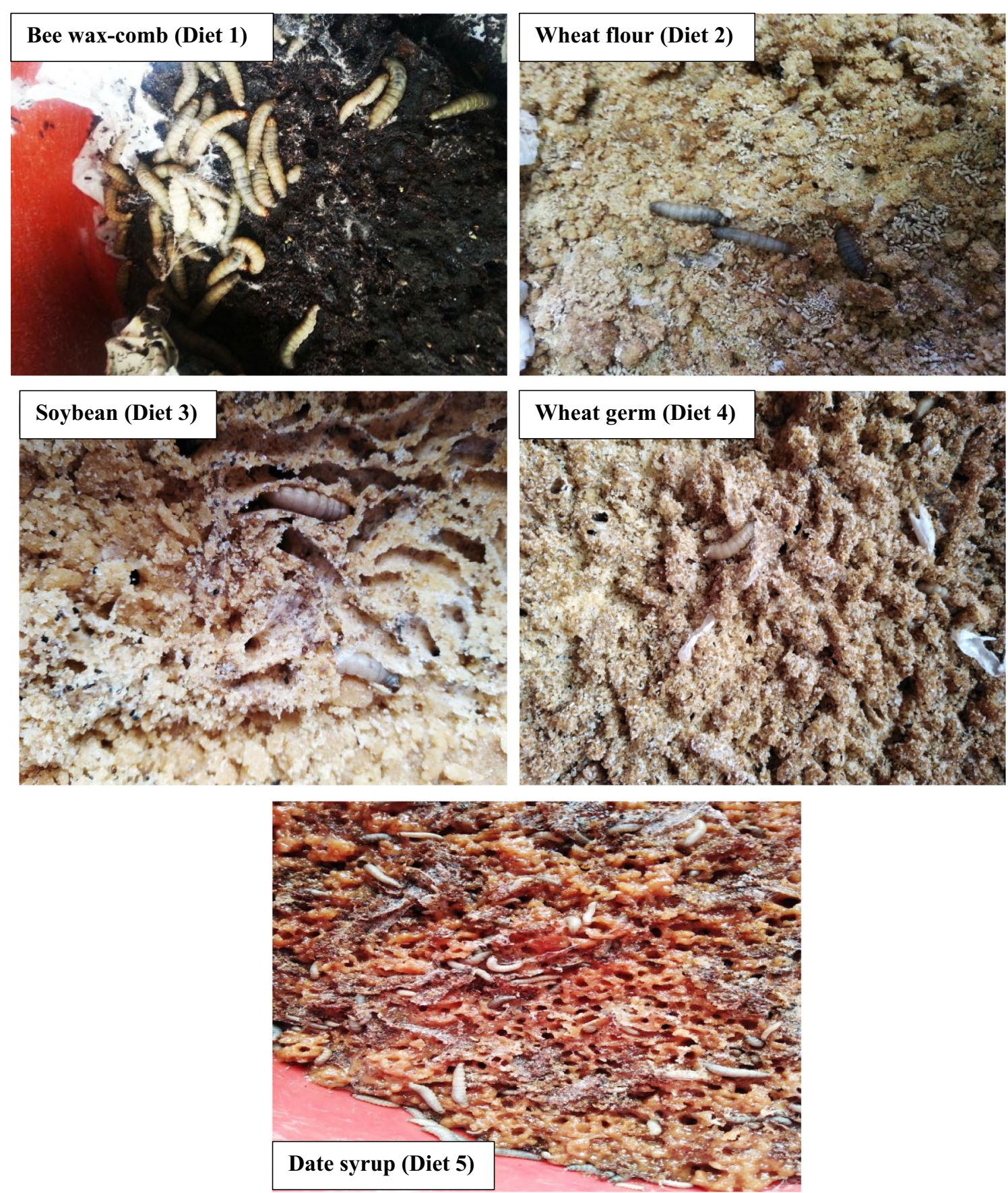

Fig. 1 Rearing the greater wax moth larvae, Galleria mellonella on five different tested diets

where: a: The number of hemocytes in 100 large squares, b: hemolymph dilution c: the number of small squares in 100 large squares.

\section{TSS \%}

The total soluble solid percentage (TSS \%) was determined in larval hemolymph from different diets $(n=10)$ by refraction index, according to the method 22.024 of the AOAC (1984) using a hand refractometer (Euromex Brix, USA).

HPC

Total protein concentration in the hemolymph $(\mathrm{mg} / 100 \mathrm{ml})$ was assayed according to the Lowry method 
(Lowry et al., 1951) using a spectrophotometer (UV2000 UV-Vis, China) at $500 \mathrm{~nm}$ wavelength in the Central Laboratory for Chemical Analysis. A standard curve was constructed by bovine serum albumin (BSA) solutions as the standard proteins. Protein determinations were repeated 10 times from each larval diet.

\section{Hemolymph content}

For this analysis, it was necessary to determine the density as well as the blood volume in the larvae from different diets. Hemolymph density $(\mathrm{mg} / \mu \mathrm{l})$ was measured by grasping each of 10 individual larva randomly from each diet, squeezing them to bleed from leg joints; taking the discharged blood in volumetrically calibrated tubes at $1 \mu \mathrm{l}$ that were pre-weighed and then reweighed the filled tubes (Carrel et al., 1990). Hemolymph volume ( $\mu \mathrm{l} /$ larva) was determined from 10 larvae individually using the radio-labeled inulin dilution method (Wharton et al., 1965) as described by the following equation:

$$
V_{b}=\left(\frac{V_{s} C_{i}}{C_{s}}\right)-V_{i}
$$

where: $\mathrm{V}_{\mathrm{b}}=$ volume of hemolymph in a larva, $\mathrm{V}_{\mathrm{s}}=$ volume of hemolymph sample, $\mathrm{V}_{\mathrm{i}}=$ volume of solution injected $(5 \mu), C_{i}=$ count of solution injected, $C_{s}=$ count of hemolymph sample.

\section{$\mathrm{DHC} \%$}

A drop of hemolymph from each 10 larvae on different diets was spread as a thin film on a clean glass slide using the edge of a cover, air dried and fixed in absolute ethanol for $20 \mathrm{~min}$. The slides were stained with Romanvsky-Giemsa stain for $12 \mathrm{~h}$, washed with distilled water and dried at room temperature. The prepared slides were examined under a light microscope (Olympus $\mathrm{CH} 2 \mathrm{O}_{\mathrm{i}}$ BIMU) by the oil-immersion lens at $\times 100$ magnifications. The hemocyte types were identified based on the key of (Ribeiro \& Brehélin, 2006; Salem et al., 2020), and the percentage of each type was calculated for each diet.

\section{Statistical analysis}

Data were statistically subjected to one-way analysis of variance (ANOVA). Data were arcsine $\sqrt{ } \mathrm{x}$ transformed before analysis to meet normality. Means were compared using Duncan's multiple range tests at $p \leq 0.05$ level (Duncan, 1955). All analyses were done with the SAS 9.1.3 program (SAS Institute, 2004).

\section{Results \\ Effect of different diets on the fitness of G. mellonella larvae \\ Water content (mg.)}

Larvae fed on old wax-comb (natural food) and soybean diets recorded an equal numbers of fresh weight (about $280 \mathrm{mg})$, which considered significantly $(p=0.0004)$ higher than the other diets (Table 2). However, the lowest weight was from date syrup-larvae (192 mg). The same trends of these tested diets were observed on dried weight larvae. Consequently, larvae from wax-comb (174.5 mg) and soybean (175.6 mg) diets had the highest water content, and then decreased gradually among the others diets. Different larval diets affected significantly on the water content $\left(F_{4,10}=12.435, p<0.001\right)$.

\section{Total protein \%}

According to the obtained results, the protein content was directly influenced by the larvae fed on different diet types $\left(F_{4,10}=8.767, p=0.003\right)$ (Table 2$)$. No significant differences were observed when larvae reared on soybean (41.87\%), wheat flour (40.52\%), wheat germ (40.92\%) and date syrup (39.51\%) diets. The only exception was on larvae from natural diet; recording the lowest proportion $(36.63 \%)$.

Table 2 Fresh \& dry weight (mg), water content $(\mathrm{mg})$, total protein \%, crude fat \% and carbohydrate \% in the fully grown larvae of Galleria mellonella fed on different diets

\begin{tabular}{lllllll}
\hline Larval diets & Fresh weight $\mathbf{( m g )}$ & Dry weight $\mathbf{( m g )}$ & Water content $\mathbf{( m g )}$ & Total protein (\%) & Crude fat (\%) & Carbohydrate (\%) \\
\hline $\begin{array}{lllllll}\text { 1-Bee wax-comb (natural- } \\
\text { food) }\end{array}$ & $280.78 \pm 6.11 \mathrm{a}$ & $106.28 \pm 2.92 \mathrm{a}$ & $174.50 \pm 4.42 \mathrm{a}$ & $36.63 \pm 0.46 \mathrm{~b}$ & $52.75 \pm 0.48 \mathrm{a}$ & $2.02 \pm 0.05 \mathrm{a}$ \\
2-Wheat flour (Standard diet) & $239.71 \pm 6.29 \mathrm{~b}$ & $88.56 \pm 2.74 \mathrm{~b}$ & $151.15 \pm 4.65 \mathrm{~b}$ & $40.52 \pm 0.59 \mathrm{a}$ & $50.93 \pm 0.50 \mathrm{ab}$ & $1.69 \pm 0.04 \mathrm{~b}$ \\
3-Soybean & $280.00 \pm 4.91 \mathrm{a}$ & $104.4 \pm 3.40 \mathrm{a}$ & $175.60 \pm 3.81 \mathrm{a}$ & $41.87 \pm 0.57 \mathrm{a}$ & $49.99 \pm 0.39 \mathrm{~b}$ & $1.97 \pm 0.05 \mathrm{a}$ \\
4-Wheat germ & $243.64 \pm 5.04 \mathrm{~b}$ & $86.00 \pm 2.88 \mathrm{~b}$ & $157.64 \pm 7.00 \mathrm{ab}$ & $40.92 \pm 0.57 \mathrm{a}$ & $52.18 \pm 0.51 \mathrm{ab}$ & $1.79 \pm 0.04 \mathrm{~b}$ \\
5-Date syrup (Dibis) & $192.01 \pm 3.54 \mathrm{C}$ & $63.22 \pm 2.15 \mathrm{C}$ & $128.79 \pm 4.39 \mathrm{C}$ & $39.51 \pm 0.40 \mathrm{a}$ & $50.92 \pm 0.50 \mathrm{ab}$ & $1.44 \pm 0.05 \mathrm{C}$ \\
F $_{4,10}$ & 39.852 & 31.063 & 12.435 & 8.767 & 3.155 & 23.110 \\
$P_{\text {ANOVA }}$ & $<0.001$ & $<0.001$ & $<0.001$ & 0.003 & 0.06 & $<0.001$
\end{tabular}

Means \pm SE sharing the same small letters in the same columns are statistically insignificant $(p>0.05)$ 


\section{Crude fat \%}

Although differences in larval crude fats were observed, but they were insignificantly $\left(F_{4,10}=3.155, p=0.06\right)$ affected by the different diets (Table 2).

\section{Carbohydrate \%}

Larvae reared on wax-comb $(2.02 \%)$ and soybean diets (1.97\%) had the highest rates of carbohydrate, followed by wheat flour $(1.69 \%)$ and wheat germ $(1.79 \%)$ diets with insignificant differences $(p=0.168)$ (Table 2). The least carbohydrate rate recorded on date syrup diet (1.44\%). Rearing larvae on different diets influenced significantly on the carbohydrate proportion $\left(F_{4,10}=23.110, p<0.001\right)$.

\section{Effect of different diets on the hemocytic parameters THC}

Total number of hemocytes in the hemolymph of full grown larvae increased significantly $\left(F_{4,45}=82.725\right.$; $p<0.001$ ) related to different diets (Table 3 ). The highest numbers of hemocytes were on larvae from soybean $\left(4746 / \mathrm{mm}^{3}\right)$ and wheat germ diets $\left(4496 / \mathrm{mm}^{3}\right)$, followed by date syrup diet $\left(4150 / \mathrm{mm}^{3}\right)$. However, larvae fed on natural diet (bee wax-comb) and the standard diet (wheat flour) as recommended previously had the lowest THC.

\section{TSS \%}

The maximum TSS\% was recorded after fed larvae on soybean $(21.7 \%)$; wheat germ $(20.9 \%)$ and wheat flour (20.3\%) diets; while those on natural diet had the lowest percentage (15.9\%) (Fig. 2). Different diets had a great impacts on TSS $\%\left(F_{4,45}=24.138 ; p<0.001\right)$.

\section{$H P C$}

Total protein concentration in the larval hemolymph was highly significantly influenced by the rearing diets $\left(F_{4,10}=291.63, p<0.001\right)$ (Table 3). Soybean diet recorded the highest HPC $(1662.5 \mathrm{mg} / 100 \mathrm{ml})$, followed by bee wax-comb and date syrup diets (1531.25, $1487.5 \mathrm{mg} / 100 \mathrm{ml}$, respectively) with insignificant differences. However, the remaining diets exhibited the least concentrations.

\section{Hemolymph content (density and volume)}

When larvae reared on soybean diet, hemolymph density showed the highest values $(3.82 \mathrm{mg} / \mu \mathrm{l})$ than the others. The density was significantly changed $\left(F_{4,45}=51.551\right.$; $p<0.001$ ) by larval nutrition's on different diets (Table 3 ). On the other hand, the larval hemolymph volume from soybean diet had the highest value (70.35 $\mu \mathrm{l} /$ larva), then date syrup diet $(66.57 \mu \mathrm{l} / \mathrm{larva})$, while the least values were on wheat flour and wheat germ diets (57.23, $56.46 \mu \mathrm{l} /$ larva), respectively. The rearing diets affected directly on the hemolymph volume $\left(F_{4,45}=31.27\right.$; $p<0.001$ ).

\section{DHC \%}

Five hemocytes types were identified in larval hemolymph, in all examined diets. These types were classified as (prohemocytes $(\mathrm{PR})$, plasmatocytes $(\mathrm{PL})$, granulocytes (GR), oenocytoids (OE) and spherulocytes (SP) (Fig. 3). The hemocytes percentages were varied greatly among the diets. Regardless the tested diets, PR type was the most frequently recorded cell type $(73.31 \%)$ in hemolymph than the other types, followed by PL (8.37\%) and the lowest type was OE cells (5.82\%) (Table 4). Under natural feeding condition of larvae on bee wax-comb and wheat germ diet, the PR \% had the highest rates (77.2\%) from the total counts, but the lowest were on soybean $(70.04 \%)$ and date syrup diets (69.8\%). However, wheat flour $(9.16 \%)$ and soybean $(9.64 \%)$ diets significantly recorded the highest PL \%. In addition, larvae from soybean diet showed superiority in percentages of

Table 3 Effect of different larval nutrition's of Galleria mellonella on the total hemocyte count $\left(\mathrm{THC} / \mathrm{mm}^{3}\right)$, hemolymph protein concentration (HPC), hemolymph density and hemolymph volume

\begin{tabular}{|c|c|c|c|c|}
\hline Larval diets & $\mathrm{THC} / \mathrm{mm}^{3}$ & $\mathrm{HPC}(\mathrm{mg} / 100 \mathrm{ml})$ & $\begin{array}{l}\text { Hemolymph density (mg/ } \\
\mu \mathrm{l})\end{array}$ & $\begin{array}{l}\text { Hemolymph } \\
\text { volume ( } \mu \mathrm{l} / \text { /larva) }\end{array}$ \\
\hline $\begin{array}{l}\text { Bee wax-comb } \\
\text { (Natural-food) }\end{array}$ & $2788 \pm 87.23 c$ & $1531.25 \pm 15.23 b$ & $2.65 \pm 0.09 b$ & $61.14 \pm 2.01 c$ \\
\hline $\begin{array}{l}\text { 2-Wheat flour } \\
\text { (Standard diet) }\end{array}$ & $2912 \pm 81.16 c$ & $1181.25 \pm 10.78 c$ & $2.39 \pm 0.07 b$ & $57.23 \pm 1.65 d$ \\
\hline 3- Soybean & $4746 \pm 98.06 a$ & $1662.50 \pm 10.99 a$ & $3.82 \pm 0.06 a$ & $70.35 \pm 1.97 a$ \\
\hline 4-Wheat germ & $4496 \pm 83.39 a$ & $1159.38 \pm 12.67 c$ & $2.43 \pm 0.09 b$ & $56.46 \pm 1.36 \mathrm{~d}$ \\
\hline $\begin{array}{l}\text { 5-Date syrup } \\
\text { (Dibis) }\end{array}$ & $4150 \pm 104.64 b$ & $1487.50 \pm 15.00 b$ & $2.50 \pm 0.06 b$ & $66.57 \pm 1.52 b$ \\
\hline$F_{4,45}$ & 82.725 & 291.63 & 51.551 & 31.274 \\
\hline$P_{\text {ANOVA }}$ & $<0.001$ & $<0.001$ & $<0.001$ & $<0.001$ \\
\hline
\end{tabular}

Means \pm SE sharing the same small letters in the same columns are statistically insignificant $(p>0.05)$ 


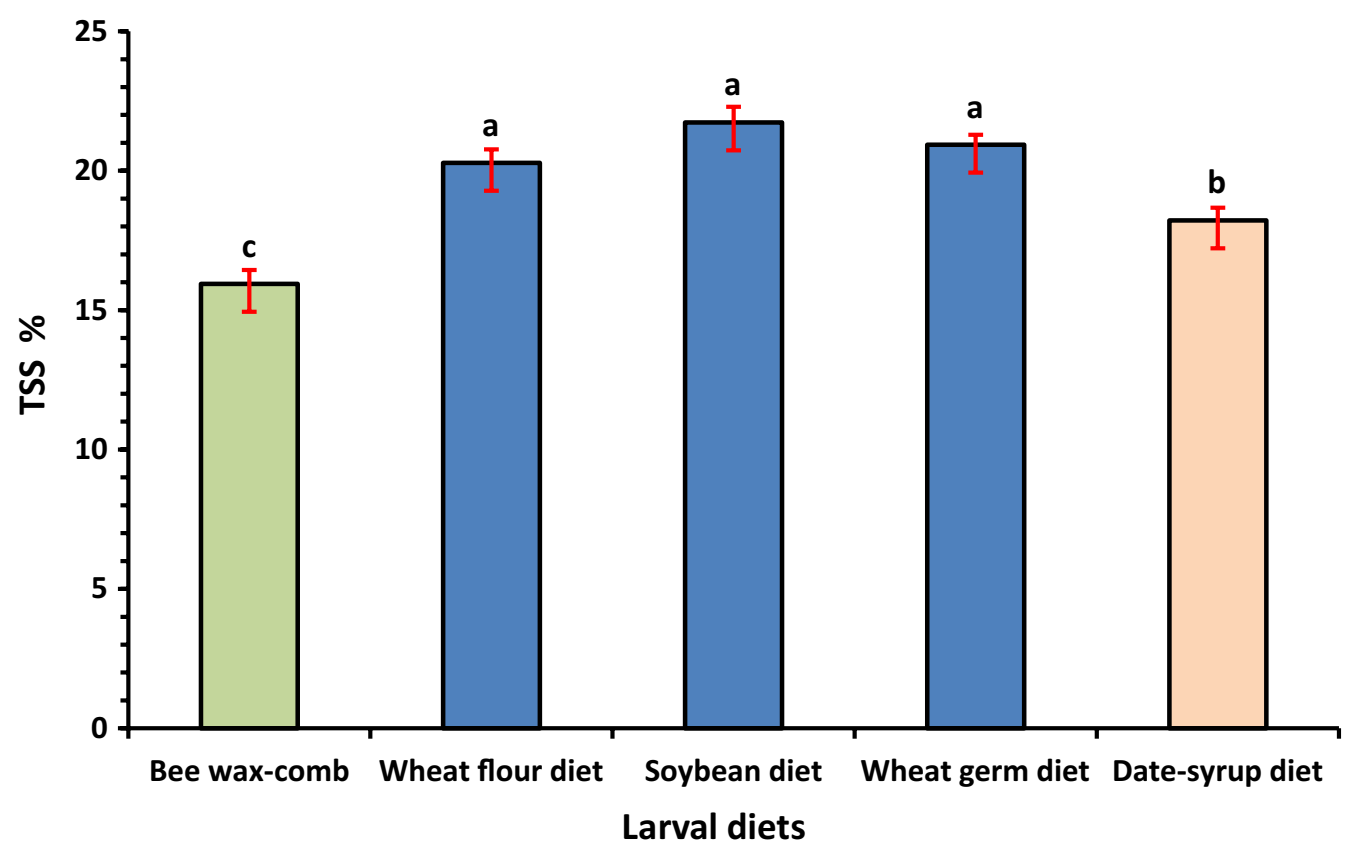

Fig. 2 Effect of different larval nutrition's of Galleria mellonella on the total soluble solids \% (TSS). Means denoted different letters are significantly different (ANOVA, $F_{4,45}=24.138 ; p<0.001$ )

GR (8.04\%) and OE cells (7.44\%), but decreased gradually on the remaining diets. In contrast, soybean diet only had unsatisfied proportion of SP (4.84\%), and the highest \% was from date syrup diet (8.74\%). Larval nutrition on different diets showed significantly variations $(p<0.001)$ on the percentages of all hemocytes types.

\section{Discussion}

Experimental Vertebrate animals are the gold standard models for in vivo assays; but ethical restrictions, high cost of using sufficient numbers of animals for statistically relevant data, and specialized training requirements led scientists to develop alternative models for in vivo experimentation (Jorjão et al., 2018). Insects' models have been shown to be useful for this purpose (Tsai et al., 2016) and had a basic innate immune system (Ramarao et al., 2012). Among certain insect models, G. mellonella is the most favorable experimental one by the scientific community.

\section{Effect of different diets on the fitness of G. mellonella larvae}

The present results recorded that larvae fed on natural bee-wax had the lowest protein rate from all diets, while the fresh weights, water contents and carbohydrates with high rates. This finding is agreeable with those reported by (Jorjão et al., 2018) that the diet with very high-energy promoting the fast development of body weight but several deficiencies on the immune system were noted. Besides, all suggested diets considered rich proteinmaterials; particularly soybean and wheat germ diets had the highest rates. Additional support to our results mentioned for a long time by (Liu, 1997; Singh et al., 2014) that soybean as an oil seed containing several useful nutrients like proteins, carbohydrates, vitamins, and minerals. Moreover, (Jorjão et al., 2018) reported that G. mellonella larvae from soybean diet had the highest fresh weights and this confirmation was in the same line with our results. In contrast, lowest weight of larvae from date-syrup diet was recorded and this may be attributed basically to the decrease in body water content due to the loss of tissue water (Wharton et al., 1965). Since the total body water content could be partitioned into two fractions: tissue water and hemolymph (Wigglesworth, 2012). Corroboration to this conclusion can be found in studies for other species such as the black soldier fly, Hermetia illucens as mentioned by (Barragan-Fonseca et al., 2019) that the highest larval weights were achieved when fed on diets with high protein and carbohydrate contents. In addition, host quality is a critical factor in evaluating the developmental rate and the fitness of emerged parasitoids reared on them (Garratt et al., 2010). Several studies have been reported the relationship between host quality and survival of developing parasitoid (bottomup effects) as well as their sex ratio, fecundity and vigor adults as mentioned previously by (Cicero et al., 2012; 


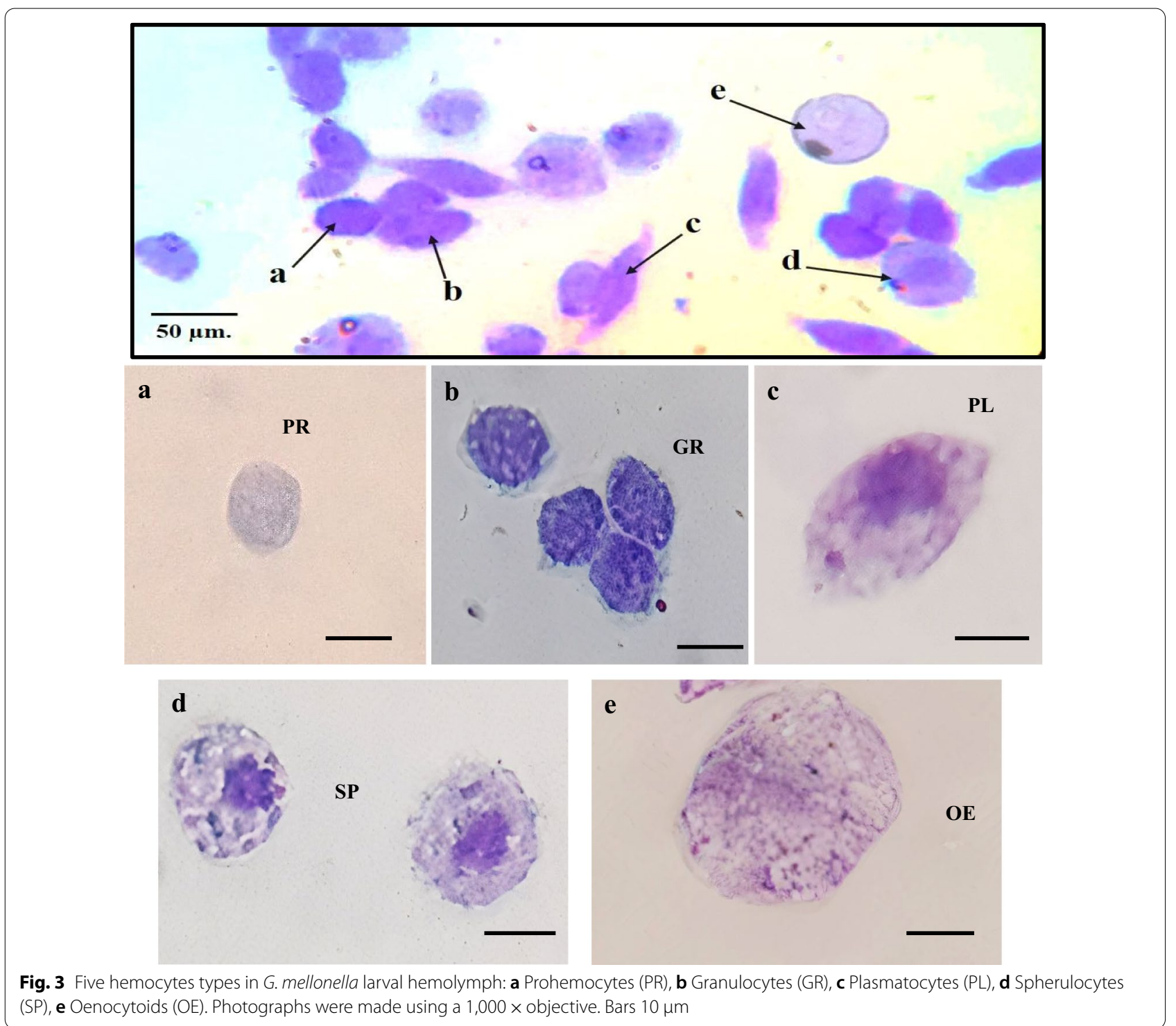

Iqbal et al., 2021; Kishani Farahani \& Goldansaz, 2013; Kishani Farahani et al., 2016; López et al., 2009). All of them confirmed that wasps from high-quality hosts survived significantly longer with high fecund than those from lower-quality ones. According to our results, the optimum diets for rearing high-quality and healthy $G$. mellonella were soybean and wheat germ diets, which offer greater nutritional resources (fresh weight, water content, protein carbohydrate); enhancing the fitness of different bio-control agents and, in turn, their efficiency in biological control programs.

\section{Effect of different larval diets on the hemocytic parameters} Insect's hemolymph plays a crucial role in transport and storage nutrients, water and salt balance, healing wounds, and immunity (Park \& Stanley, 2006; Durmus et al., 2008). In addition, hemocytes are very important in recognition of foreign materials by phagocytosis or encapsulation; synthesis of reactive oxygen and nitrogen species; peptides and proteins engaged in immunity; and management of nutritional elements (Bogaerts et al., 2009). The present study suggested a suitable diet that provides larvae with suitable THC, TSS \%, HPC and amounts of hemolymph (volume and density) for in vivo experimentation. Among these tested diets, larvae from soybean, followed by wheat germ diets had the achieved results than those from natural food and standard diets (wheat flour). In this concept, (Jorjão et al., 2018) clarified that HPC reflected the quality of protein diets used for feeding G. mellonella larvae. Moreover, as reported 
Table 4 Differential hemocyte counts \% (DHC) on the larval hemolymph of Galleria mellonella fed on different diets

\begin{tabular}{|c|c|c|c|c|c|}
\hline \multirow[t]{2}{*}{ Larval diets } & \multicolumn{5}{|l|}{ DHC \% } \\
\hline & Prohemocytes & Plasmatocytes & Granulocytes & Oenocytoids & Spherulocytes \\
\hline $\begin{array}{l}\text { 1-Bee wax-comb } \\
\text { (natural-diet) }\end{array}$ & $77.20 \pm 0.26 a$ & $8.28 \pm 0.32 b$ & $4.32 \pm 0.29 d$ & $5.19 \pm 0.31 b$ & $5.01 \pm 0.24 c$ \\
\hline $\begin{array}{l}\text { 2-Wheat flour } \\
\text { (Standard diet) }\end{array}$ & $72.24 \pm 0.24 b$ & $9.16 \pm 0.55 \mathrm{a}$ & $5.88 \pm 0.24 c$ & $5.99 \pm 0.34 b$ & $6.73 \pm 0.23 b$ \\
\hline 3-Soybean & $70.04 \pm 0.99 c$ & $9.64 \pm 0.62 \mathrm{a}$ & $8.04 \pm 1.87 \mathrm{a}$ & $7.44 \pm 0.58 \mathrm{a}$ & $4.84 \pm 0.20 d$ \\
\hline 4-Wheat germ & $77.28 \pm 0.26 \mathrm{a}$ & $6.08 \pm 0.29 c$ & $5.08 \pm 0.26 c$ & $5.48 \pm 0.33 b$ & $6.08 \pm 0.31 b$ \\
\hline $\begin{array}{l}\text { 5-Date syrup } \\
\text { (Dibis) }\end{array}$ & $69.80 \pm 0.20 c$ & $8.68 \pm 0.42 b$ & $7.82 \pm 0.60 b$ & $5.01 \pm 0.21 b$ & $8.74 \pm 0.27 a$ \\
\hline $\begin{array}{l}\text { Overall average \% } \\
\text { (ranking order) }\end{array}$ & $\begin{array}{l}73.31 \\
(1)\end{array}$ & $\begin{array}{l}8.37 \\
(2)\end{array}$ & $\begin{array}{l}6.23 \\
(4)\end{array}$ & $\begin{array}{l}5.82 \\
(5)\end{array}$ & $\begin{array}{l}6.28 \\
(3)\end{array}$ \\
\hline$F_{4,120}$ & 22.82 & 51.264 & 203.742 & 66.833 & 14.57 \\
\hline$P_{\text {ANOVA }}$ & $<0.001$ & $<0.001$ & $<0.001$ & $<0.001$ & $<0.001$ \\
\hline
\end{tabular}

Means \pm SE sharing the same small letters in the same columns are statistically insignificant $(p>0.05)$

by (Krams et al., 2015) the diet composition had a significant effect on their immune system activity. The increase of THC (Salem et al., 2020), TSS \% (Kludkiewicz et al., 2019) and HPC (Carrel et al., 1990) revealed the active status of insect metabolism, and hence used as an indicator for the hemolymph functional efficiency (Glinski \& Klimont, 1987). These findings were agreeable with that noted on larvae from soybean diet. Subsequently, food deprivation or lack of protein in the diet caused considerable changes in functioning and structure of the cellular system; and thus decreasing the immune response activity (Siva-Jothy \& Thompson, 2002; Stączek et al., 2020). Many reports demonstrated that hemolymph is the water reservoir and their volume varied considerably by many factors such as age, developmental status, diet, rearing conditions and hydration state (Barakat \& Meshrif, 2007). Increasing the blood volume in our study was related to rear larvae on different diets.

Under light microscope examination, five types of hemocytes (PR, PL, GR, OE and SP) in the larval hemolymph were identified, but with different proportions, based on the diet type. Several studies have been classified the same hemocyte types in G. mellonella under different conditions as previously reported by (Kurt \& KAYIŞ, 2017; Boguś et al., 2018; Senior \& Titball, 2020). Other researchers described four types only (PL, GR, SP and OE) (Sezer \& Ozalp, 2015; Wu et al., 2016), but (Kavanagh \& Reeves, 2004) noted six types (PR, PL, GR, $\mathrm{SP}, \mathrm{OE}$ and coagulocytes). Contrary to our results, (Salem et al., 2020) distinguished eight cell types (PR, PL, GR, SP, OE, spindle cells, adipohemocytes and cystocytes). These variations in hemocyte types maybe due to the use of staining affinity (Wu et al., 2016) or the different larval instars used in the study (Salem et al., 2020). The morphological features and relative abundances of different hemocyte types were considered as criteria for the physiological condition of G. mellonella (Senior \& Titball, 2020). Thereafter, a significant increase in the proportions of PL, GR and OE cells were observed in the larval hemolymph from soybean diet in comparable to natural beewax. This observation is in consistence with (Altuntaş et al., 2021) who observed that diets with low protein value led to a significant change in the percentage of GR cells. The PL and GR cells being the major immunological cell types in insects (Coskun et al., 2020); involving in the cellular defense against pathogens (Stączek et al., 2020). Moreover, the GR cells exhibited the strongest phagocytic ability than the other types (Wu et al., 2016). PR cells were the most frequently recorded cell type in all tested diet in the present study and this concept was agreeable with those reported by (Salem et al., 2020). On the other hand, SP cell type \% was significantly increased in larvae fed on wheat germ diet than natural bee-wax. Regarding to the observation made by (Salem et al., 2020; Staczek et al., 2020) that SP was considered as immunocompetent cells and had a key role in phagocytosis and encapsulation; and thus may reflect their importance in improving the larval physiological condition. Ultimately, this study might provide new insight into the different roles of these nutritional diets in enhancing and improving the fitness and immunity of G. mellonella larva to obtain an ideal model for further research.

\section{Conclusions}

This study is an attempt to mass rearing G. mellonella larvae with available, ease and low expenses ingredients' diets for producing high numbers of healthy, vigor and quality larvae for biological purposes as an insect model. 
In the light of overall results, soybean and wheat germ diets can act positively on the larval immune system; offering greater nutritional resources for larval fitness and hence could be recommended as standard diets for rearing high-quality G. mellonella.

\section{Abbreviations}

THC: Total hemocyte count; TSS: Total soluble solid; HPC: Hemolymph protein concentration; DHC: Differential hemocyte counts; PR: Prohemocytes; PL: Plasmatocytes; GR: Granulocytes; OE: Oenocytoids; SP: Spherulocytes.

\section{Acknowledgements}

The authors acknowledged Prof. Dr. Adham Mostafa, Bee Research Department, Plant Protection Research Institute, Agricultural Research Center, for offering the initial culture of G. mellonella and the wax-comb (natural food) used in this study. Special thanks to Dr. Omaima Saber for her moral support, keen interest and help.

\section{Authors' contributions}

Both authors of this manuscript contributed equally to the design and/or execution of the experiments described in the manuscript. HOM prepared and edited the final version of this manuscript. All authors approved the final manuscript.

\section{Funding}

This work was not supported by any funding body, but personally financed.

\section{Availability of data and materials}

All data and materials used and/or analyzed during the current study are available in this manuscript.

\section{Declarations}

Ethics approval and consent to participate

Not applicable.

\section{Consent for publication}

Not applicable.

\section{Competing interests}

The authors declare that they have no competing interests.

\section{Author details}

${ }^{1}$ Biological Control Research Department, Plant Protection Research Institute, Agricultural Research Center, Giza, Egypt. Bee Research Department, Plant Protection Research Institute, Agricultural Research Center, Giza, Egypt.

Received: 3 March 2021 Accepted: 17 February 2022

Published online: 03 March 2022

\section{References}

Altuntaş, H., Gwokyalya, R., \& Bayram, N. (2021). Immunotoxic effects of force-fed ethephon on model organism Galleria mellonella (Lepidoptera: Pyralidae). Drug and Chemical Toxicology, 1-8.

AOAC (Association of Official Analytical Chemists). (1984). Official methods of analysis (14th ed.). AOAC.

AOAC. (2000). Official methods and recommended practices of the American Oil Chemists' Society, 5th ed. Am Oil Chem Soc, Champaingn

AOCS. Oxirane Oxygen, Official and Recommended Methods of the American Oil Chemists' Society, 3rd edn., American Oil Chemists' Society, Champaign, Method Cd 9-57, reapproved 1989

Ashfaq, M., Al-Tememi, N. K., \& Ahmed, S. (2005). Effect of artificial diets on some parameters of greater wax moth Galleria mellonella L. under optimum conditions. Journal of Agricultural Research, 43(3), 223-228.
Barakat, E. M. S., \& Meshrif, W. S. (2007). Physiological changes in the desert locust, Schistocerca gregaria F. in response to diet and injection with Bacillus thuringiensis. Journal of Environmental Science, 3, 210-239.

Barragan-Fonseca, K. B., Gort, G., Dicke, M., \& Van Loon, J. J. (2019). Effects of dietary protein and carbohydrate on life-history traits and body protein and fat contents of the black soldier fly Hermetia illucens. Physiological Entomology, 44(2), 148-159.

Bogaerts, A., Baggerman, G., Vierstraete, E., Schoofs, L., \& Verleyen, P. (2009). The hemolymph proteome of the honeybee: Gel-based or gel-free? Proteomics, 9(11), 3201-3208.

Boguś, M. I., Ligęza-Żuber, M., Polańska, M. A., Mosiewicz, M., Włóka, E., \& Sobocińska, M. (2018). Fungal infection causes changes in the number, morphology and spreading ability of Galleria mellonella haemocytes. Physiological Entomology, 43(3), 214-226.

Bounias, M., \& Morgan, M. R. J. (1990). Effect of sucrose feeding on the induction of honey bee haemolymph a-Glucosidase (EG 3.2 1.20). Journal of Apicultural Research, 29(4), 181-186.

Brennan, M., Thomas, D. Y., Whiteway, M., \& Kavanagh, K. (2002). Correlation between virulence of Candida albicans mutants in mice and Galleria melIonella larvae. FEMS Immunology \& Medical Microbiology, 34(2), 153-157.

Büyükgüzel, K. (2006). Malathion-induced oxidative stress in a parasitoid wasp: Effect on adult emergence, longevity, fecundity, and oxidative and antioxidative response of Pimpla turionellae (Hymenoptera: Ichneumonidae). Journal of Economic Entomology, 99(4), 1225-1234.

Carrel, J. E., Wood, J. M., Yang, Z., McCairel, M. H., \& Hindman, E. E. (1990). Diet, body water, and hemolymph content in the blister beetle Lytta polita (Coleoptera: Meloidae). Environmental Entomology, 19(5), 1283-1288.

Cicero, L., Sivinski, J., \& Aluja, M. (2012). Effect of host diet and adult parasitoid diet on egg load dynamics and egg size of braconid parasitoids attacking Anastrephaludens. Physiological Entomology, 37(2), 177-184.

Chandel, Y. S., Sharma, S., \& Verma, K. S. (2003). Comparative biology of the greater wax moth, Galleria mellonella L., and lesser wax moth, Achoria grisella. Forest Pest Management and Economic Zoology, 11, 69-74

Coskun, M., Kayis, T., Gulsu, E., \& Alp, E. (2020). Effects of selenium and vitamin E on enzymatic, biochemical, and immunological biomarkers in Galleria mellonella L. Scientific Reports, 10(1), 1-7.

Duncan, D. B. (1955). Multiple range and multiple F tests. Biometrics, 11(1), $1-42$.

Durmuş, Y., Büyükgüzel, E., Terzi, B., Tunaz, H., Stanley, D., \& Büyükgüzel, K. (2008). Eicosanoids mediate melanotic nodulation reactions to viral infection in larvae of the parasitic wasp, Pimpla turionellae. Journal of Insect Physiology, 54(1), 17-24.

Garratt, M. P., Leather, S. R., \&Wright, D. J. (2010). Tritrophic effects of organic and conventional fertilisers on a cereal-aphid-parasitoid system. Entomologia Experimentalis Et Applicata, 134(3), 211-219.

Gliński, Z., \& Klimont, S. (1987). Effect of Varroa jacobsoni invasion on the cells in the haemolymph of worker bees Apis mellifera L. Medycyna Weterynaryjna, 43, 546-549.

Gwokyalya, R., \& Altuntas, H. (2019). Boric acid-induced immunotoxicity and genotoxicity in model insect Galleria mellonella L. (Lepidoptera: Pyralidae). Archives of Insect Biochemistry and Physiology, 101(4), e21588.

Hanumanthaswamy, B. C., \& Rajagopal, D. (2017). Natural enemies of greater wax moth Galleria mellonella Linnaeus in honey bee colonies. International Journal of Current Microbiology and Applied Sciences, 6(8), 3418-3421.

Hasan, M., Yeasmin, L., Athanassiou, C. G., Bari, M., \& Islam, M. (2019). Using gamma irradiated Galleria mellonella L. and Plodia interpunctella (Hübner) larvae to optimize mass rearing of parasitoid Habrobracon hebetor (Say) (Hymenoptera: Braconidae). Insects, 10(8), 223.

Hedge, J. E., Hofreiter, B. T., \& Whistler, R. L. (1962). Carbohydrate chemistry (p. 17). Academic Press.

Iqbal, A., Chen, Y. M., Hou, Y. Y., Ruan, C. C., Desneux, N., Khan, M. Q., \& Zang, L. S. (2021). Rearing Trichogramma ostriniae on the factitious host Antheraea pernyi via multiparasitism with Trichogramma chilonis facilitates enhanced biocontrol potential against Ostrinia furnacalis. Biological Control, 156, 104567.

Jindra, M., \& Sehnal, F. (1989). Larval growth, food consumption, and utilization of dietary protein and energy in Galleria mellonella. Journal of Insect Physiology, 35(9), 719-724.

Jorjão, A. L., Oliveira, L. D., Scorzoni, L., Figueiredo-Godoi, L. M., Cristina, A., Prata, M., Jorge, A. O., \& Junqueira, J. C. (2018). From moths to caterpillars: 
Ideal conditions for Galleria mellonella rearing for in vivo microbiological studies. Virulence, 9(1), 383-389.

Kandil, M. A., Moustafa, H. Z., \& Lotfy, D. E. (2020). Behavior and generation times of Bracon brevicornis (Wesmael) (Hymenoptera: Bracondae) reared on Pectinophora gossypiella (Saunders) (Lepidoptera: Gelechiidae) and Galleria mellonella (Lepidoptera: Pyralidae). International Journal of Tropical Insect Science, 15, 1-8.

Kavanagh, K., \& Reeves, E. P. (2004). Exploiting the potential of insects for in vivo pathogenicity testing of microbial pathogens. FEMS Microbiology Reviews, 28(1), 101-112.

Kaya, S., Uçkan, F., \& Er, A. (2020). Influence of indole-3-acetic acid on cellular immune responses of Galleria mellonella L. (Lepidoptera: Pyralidae) and Pimpla turionellae L. (Hymenoptera: Ichneumonidae) in a host-parasitoid system. International Journal of Tropical Insect Science, 41(1), 169-179.

Kirk, P. L. (1950). Kjeldahl method for total nitrogen. Analytical Chemistry, 22(2), 354-358.

Kishani Farahani, H., \& Goldansaz, S. H. (2013). Is host age an important factor in the bionomics of Apanteles myeloenta (Hymenoptera: Braconidae)? European Journal of Entomology, 110(2), 277-283.

Kishani Farahani, H., Ashouri, A., Zibaee, A., Abroon, P., \& Alford, L. (2016). The effect of host nutritional quality on multiple components of Trichogramma brassicae fitness. Bulletin of Entomological Research, 106(5), 633-641.

Kludkiewicz, B., Kucerova, L., Konikova, T., Strnad, H., Hradilova, M., Zaloudikova, A., Sehadova, H., Konik, P., Sehnal, F., \& Zurovec, M. (2019). The expansion of genes encoding soluble silk components in the greater wax moth, Galleria mellonella. Insect Biochemistry and Molecular Biology, 106, 28-38.

Krams, I., Kecko, S., Kangassalo, K., Moore, F. R., Jankevics, E., Inashkina, I., Krama, T., Lietuvietis, V., Meija, L., \& Rantala, M. J. (2015). Effects of food quality on trade-offs among growth, immunity and survival in the greater wax moth Galleria mellonella. Insect Science, 22(3), 431-439.

Kulkarni, N., Kushwaha, D. K., Mishra, V. K., \& Paunikar, S. (2012). Effect of economical modification in artificial diet of greater wax moth Galleria mellonella (Lepidoptera: Pyralidae). Indian Journal of Entomology, 74(4), 369-374.

Kurt, D., \& Kayiş, T. (2017). Effects of the pyrethroid insecticide deltamethrin on the hemocytes of Galleria mellonella. Turkish Journal of Zoology, 39(3), 452-457.

Kwadha, C. A., Ongamo, G. O., Ndegwa, P. N., Raina, S. K., \& Fombong, A. T. (2017). The biology and control of the greater wax moth, Galleria mellonella. Insects, 8(2), 61.

Liu, K. S. (1997). Chemistry and nutritional value of soybean components. Soybean: Chemistry, technology, and utilization (pp. 25-113). Chapman \& Hall.

Loh, J. M., Adenwalla, N., Wiles, S., \& Proft, T. (2013). Galleria mellonella larvae as an infection model for group A streptococcus. Virulence, 4(5), 419-428.

López, O. P., Hénaut, Y., Cancino, J., Lambin, M., Cruz-López, L., \& Rojas, J. C. (2009). Is host size an indicator of quality in the mass-reared parasitoid Diachasmimorpha longicaudata (Hymenoptera: Braconidae)? Florida Entomologist, 92(3), 441-449.

Lowry, O. H., Rosebrough, N. J., Farr, A. L., \& Randall, R. J. (1951). Protein measurement with the Folin phenol reagent. Journal of Biological Chemistry, $193,265-275$

Metwally, H. M., Hafez, G. A., Hussein, M. A., Hussein, M. A., Salem, H. A., \& Saleh, M. M. (2012). Low cost artificial diet for rearing the greater wax moth, Galleria mellonella L. (Lepidoptera: Pyralidae) as a host for entomopathogenic nematodes. Egyptian Journal of Biological Pest Control, 22(1), 15.

Miyata, S., Casey, M., Frank, D. W., Ausubel, F. M., \& Drenkard, E. (2003). Use of the Galleria mellonella caterpillar as a model host to study the role of the type III secretion system in Pseudomonas aeruginosa pathogenesis. Infection and Immunity, 71(5), 2404-2413.

Mohamed, A. A., Ansari, M. J., Al-Ghamdi, A., Mohamed, M. O., \& Kaur, M. (2014). Effect of larval nutrition on the development and mortality of Galleria mellonella (Lepidoptera: Pyralidae). Revista Colombiana De Entomología, 40(1), 49-54.

Mukherjee, K., Altincicek, B., Hain, T., Domann, E., Vilcinskas, A., \& Chakraborty, T. (2010). Galleria mellonella as a model system for studying Listeria pathogenesis. Applied and Environmental Microbiology, 76(1), 310-317.

Mylonakis, E., Moreno, R., El Khoury, J. B., Idnurm, A., Heitman, J., Calderwood, S. B., Ausubel, F. M., \& Diener, A. (2005). Galleria mellonella as a model system to study Cryptococcus neoformans pathogenesis. Infection and Immunity, 73(7), 3842-3850.
Olsen, R. J., Watkins, M. E., Cantu, C. C., Beres, S. B., \& Musser, J. M. (2011). Virulence of serotype M3 Group A Streptococcus strains in wax worms (Galleria mellonella larvae). Virulence, 2(2), 111-119.

Park, Y., \& Stanley, D. (2006). The entomopathogenic bacterium, Xenorhabdus nematophila, impairs hemocytic immunity by inhibition of eicosanoid biosynthesis in adult crickets, Gryllus firmus. Biological Control, 38(2), 247-253.

Predetshensky, V. E., Parovska, V. M., \& Margolina, L. T. (1950). Microtechnique methods. Goso Uzd Medgez Moskva (in Russian), 125, 115-121.

Rabie, A. L., Wells, J. D., \& Dent, L. K. (1983). The nitrogen content of pollen protein. Journal of Apicultural Research, 22(2), 119-123.

Ramarao, N., Nielsen-Leroux, C., \& Lereclus, D. (2012). The insect Galleria mellonella as a powerful infection model to investigate bacterial pathogenesis. Journal of Visualized Experiments, 70, e4392.

Ribeiro, C., \& Brehélin, M. (2006). Insect haemocytes: What type of cell is that? Journal of Insect Physiology, 52(5), 417-429.

Salem, H. M., Hussein, M. A., Hafez, S. E., Hussein, M. A., \& Sayed, R. M. (2020). Hemocytic studies on the synergistic effect of the entomopathogenic nematode species, Steinernema carpocapsae and gamma radiation on the greater wax moth, Galleria mellonella (L.) larvae. Egyptian Journal of Biological Pest Control, 30, 1-9.

SAS Institute, (2004): The SAS System Version 9.1.3. SAS Institute, Cary, NC.

Senior, N. J., \& Titball, R. W. (2020). Isolation and primary culture of Galleria mellonella hemocytes for infection studies. F1000Research, 9(1392), 1-17.

Sezer, B., \& Ozalp, P. (2015). Effects of pyriproxyfen on hemocyte count and morphology of Galleria mellonella. Fresenius Environmental Bulletin, 24(2a), 621-625.

Singh, S. P., Swati, R., \& Singh, J. (2014). Effect of artificial diet composition on some biological parameters of greater wax moth, Galleria mellonella $\mathrm{L}$. under laboratory conditions. Journal of Advanced Studies in Agricultural, Biological and Environmental Sciences, 1(2), 243-246.

Siva-Jothy, M. T., \& Thompson, J. J. (2002). Short-term nutrient deprivation affects immune function. Physiological Entomology, 27(3), 206-212.

Slater, J. L., Gregson, L., Denning, D. W., \& Warn, P. A. (2011). Pathogenicity of Aspergillus fumigatus mutants assessed in Galleria mellonella matches that in mice. Medical Mycology, 49(1), S107-S113.

Sohail, M., Aqueel, M. A., Ellis, J. D., Afzal, M., \& Raza, A. M. (2017). Seasonal abundance of greater wax moths (Galleria mellonella $\mathrm{L}$.) in hives of western honey bees (Apis mellifera L.) correlates with minimum and maximum ambient temperature. Journal of Apicultural Research, 56(4), 416-420.

Stączek, S., Zdybicka-Barabas, A., Wiater, A., Pleszczyńska, M., \& Cytryńska, M. (2020). Activation of cellular immune response in insect model host Galleria mellonella by fungal a-1, 3-glucan. Pathogens and Disease, 78(9), ftaa062.

Tsai, C. J., Loh, J. M., \& Proft, T. (2016). Galleria mellonella infection models for the study of bacterial diseases and for antimicrobial drug testing. Virulence, 7(3), 214-229.

Van Zyl, C., \& Malan, A. P. (2015). Cost-effective culturing of Galleria mellonella and Tenebrio molitor and entomopathogenic nematode production in various hosts. African Entomology, 23(2), 361-375.

Wharton, D. R., Wharton, M. L., \& Lola, J. (1965). Blood volume and water content of the male American cockroach, Periplaneta americana L.-Methods and the influence of age and starvation. Journal of Insect Physiology, 11(4), 391-404.

Wigglesworth, V. B. (2012). The principles of insect physiology, 7th edn. Springer

Wojda, I. (2017). Immunity of the greater wax moth Galleria mellonella. Insect Science, 24, 342-357.

Wu, G., Liu, Y., Ding, Y., \& Yi, Y. (2016). Ultrastructural and functional characterization of circulating hemocytes from Galleria mellonella larva: Cell types and their role in the innate immunity. Tissue and Cell, 48(4), 297-304.

\section{Publisher's Note}

Springer Nature remains neutral with regard to jurisdictional claims in published maps and institutional affiliations. 